\title{
A CONSTRUÇÃO E O DESENVOLVIMENTO DA SEXUALIDADE A PARTIR DA PERSPECTIVA DA PERSONAGEM POMBINHA EM O CORTIÇO, DE ALUÍSIO AZEVEDO
}

\section{THE CONSTRUCTION AND THE DEVELOPMENT OF SEXUALITY FROM THE PERSPECTIVE OF THE CHARACTER POMBINHA, IN O CORTIÇO, BY ALUÍSIO AZEVEDO}

\author{
Juscelino Francisco do Nascimento ${ }^{1}$ \\ Igor Kisser Macedo Carvalho
}

Recebido em: 23 set. 2018

Aceito em: 29 dez. 2018

DOI 10.26512/aguaviva.v3i3.22162

RESUMO: Este trabalho discute a construção e o desenvolvimento da sexualidade e do erotismo feminino na obra $O$ cortiço ([1890] 2012), de Aluísio Azevedo. Em meados do século XIX, a mulher desempenhava papel secundário na sociedade vigente, sendo submissa aos homens e tendo como meio principal os ambientes domésticos, sendo limitadas às práticas sexuais apenas dentro do matrimônio. Aluísio Azevedo apresenta uma personagem marcada pelo seu desenvolvimento sexual, que passa de impúbere para prostituta, tendo relações libidinosas com outra mulher e um casamento que não lhe é de bom grado. Destacamos que o Naturalismo adotou as patologias sexuais como uma de suas principais temáticas, pois retrata o sexo como um comportamento marginalizado e vicioso. A partir desses pressupostos, notase que o comportamento de Pombinha nos permite ter uma visão mais ampla da sexualidade da figura feminina.

Palavras-chave: Sexualidade; Erotismo; Patologia Sexual; Naturalismo.

ABSTRACT: This paper discusses the construction and development of sexuality and female eroticism in $O$ Cortiço ([1890] 2012), by Aluísio Azevedo. In the middle of the nineteenth century, women played a secondary role in that society, being submissive to men and having as main entourage domestic environments, being limited to sexual practices only within marriage. Aluísio Azevedo presents a character marked by her sexual development, that passes

\footnotetext{
${ }^{1}$ Doutorando em Linguística pela Universidade de Brasília (UnB), membro do Grupo de Estudos Críticos e Avançados em Linguagens (GECAL/UnB), do Grupo de Pesquisa (Socio)Linguística, Letramentos Múltiplos e Educação (SOLEDUC/UnB) e do Grupo de Pesquisa Linguagem, Escola e Sociedade (LES/UFPI). Professor Assistente da Universidade Federal do Piauí (UFPI), Campus Senador Helvídio Nunes de Barros, Picos/PI. Email: juscelinosampa@hotmail.com

${ }^{2}$ Graduado em Letras/Português pela Universidade Federal do Piauí (UFPI), Campus Senador Helvídio Nunes de Barros, Picos/PI. E-mail: igor.kisser91@outlook.com
} 
of impuber to the prostitute, having libidinous relations with another woman and a marriage that does not to her willingly. We emphasize that Naturalism has adopted sexual pathologies as one of its main themes, for it portrays sex as a marginalized and vicious behavior. From these assumptions, it is noted that the behavior of Pombinha allows us to have a broader view of sexuality and female figure.

Keywords: Sexuality; Eroticism; Sexual Pathology; Naturalism.

\section{INTRODUÇÃO}

Este trabalho tem como temática a sexualidade presente na personagem Pombinha, do romance naturalista $O$ Cortiço ([1890] 2012), de Aluísio Azevedo. Desta maneira, este estudo se configura em mostrar a construção e o desenvolvimento sexual da personagem mencionada. Diante disso, esse artigo possui a problemática de investigar e demonstrar as mudanças provocadas pela evolução sexual feminina, desde a fase impúbere à independência e prostituição.

No que tange à hipótese, apoiamo-nos em estudos sobre o tema já mencionado, surgindo a conceituação específica de erotismo e sexualidade nos romances naturalistas. Tendo como base os textos sobre a temática especificada, partimos para textos que tratassem do diálogo entre literatura e sociedade e as particularidades da estética naturalista. Bataille (2013), Bosi (2006), Castello Branco (1984) e (2004), Candido (2000), Coutinho (2004), Foucault (1988), entre outros, foram autores fundamentais para compreensão e análise da obra sob a perspectiva do tema adotado.

Diante disso, esse estudo também busca refletir sobre a temática erótica naturalista, procurando situar a obra $O$ Cortiço ([1890] 2012) em seu contexto histórico. Além disso, essa pesquisa objetiva abarcar a construção e o desenvolvimento da sexualidade sob a ótica da personagem Pombinha, identificando a força erótica sexual da mulher naturalista e focando, principalmente, em aspectos que evidenciam o desenvolvimento da sexualidade nos romances naturalistas.

O interesse de pesquisar sobre este tema está relacionado à posição que a personagem tinha dentro do seu contexto social, visto que as características e a sexualidade explicitada eram adversas às normas e regras da época, entendendo que o século XIX, momento situado do romance naturalista de Aluísio Azevedo, era engajado por uma sociedade cristã, preenchida pelos seus alicerces morais e repreendendo qualquer explicitação de sexualidade. 
O corpus desta pesquisa é composto pelo livro O Cortiço ([1890] 2012), que retrata uma habitação coletiva no Rio de Janeiro do final do século XIX. O Cortiço ([1890] 2012) é, em suma, uma tese determinista e mostra como o homem é suscetível às forças sociais e naturais maiores que ele: o meio em que vive, a sua raça e o seu momento histórico. Na obra, o autor traça um retrato da sordidez e dos vícios humanos.

O livro tem diversos personagens marcantes, que vão se corrompendo no decorrer da narrativa. Assim, não há um protagonista específico, pois, mais forte que todos eles, é o próprio Cortiço, que, como fora personificado, possui uma história própria e cresce no decorrer da trama.

Diversas histórias relacionam-se para construir a do Cortiço, símbolo do meio social que corrompe o indivíduo, tendo mais força do que o caráter ou a vontade individual. Alguns personagens ganham destaque na narrativa, entre eles, Pombinha, adolescente pura e estudada, a qual será analisada e inserida no contexto referente à sexualidade e ao erotismo.

A obra é claramente de cunho determinista que, como uma teia que vai amarrando e dominando a presa, demonstra-se por meio dos personagens que se corrompem. Além disso, sob influência darwinista, é o mais "forte" quem sempre obtém sucesso.

Esta pesquisa tem caráter analítico-descritivo, visto que trabalha com a análise e discussão da obra supramencionada, tendo como foco de análise a construção e desenvolvimento da personagem Pombinha. Assim sendo, parte do levantamento bibliográfico acerca do tema proposto é composto por estudos de teoria, crítica e história literária, em especial sobre a estética naturalista, sociológicos e estudos sobre sexualidade e erotismo.

A análise será feita na perspectiva erótico-sexual, sob os vieses sociais e culturais a partir do contexto histórico do romance, fundamentando-se em alguns princípios dos estudos de Bataille (2013), Castelo Branco (1985; 2004) e Foucault (2006).

Em relação à organização deste artigo, ele se estrutura em três seções: a primeira retrata o contexto histórico das estéticas do Realismo e do Naturalismo, e aborda as principais características dessas correntes literárias, que surgiram no século XIX; a segunda trata da sexualidade feminina e a ascensão do discurso sexual no contexto em estudo, destacando a repressão do cristianismo e do cientificismo no que diz respeito às práticas sexuais e o papel da mulher nesse período; a última seção traz a análise do romance em estudo, apresentando, na narrativa, aspectos ligados à sexualidade da personagem Pombinha, com o intuito de explanar sobre a construção e o desenvolvimento referente à sua sexualidade. 


\section{Naturalismo: a ficção representativa da sociedade brasileira no século XIX em $O$ Cortiço}

Na segunda metade do século XIX, a economia açucareira já em declínio e os anseios das classes médias urbanas, em consequência do aumento da industrialização, propiciando a fermentação de ideias liberais, abolicionistas e republicanas, compunham um novo molde de nação. A esse respeito, segundo Bosi (2006, p. 163), “de 1870 a 1890 serão essas as teses esposadas pela inteligência nacional, cada vez mais permeável ao pensamento europeu que na época se constelava em torno da filosofia positiva do evolucionismo".

De acordo com Coutinho (2004, p. 17), “de uma sociedade agrária, latifundiária, escravocrata, aristocrática, passava-se para uma civilização burguesa e urbana, fase preparatória da industrialização". Nesse sentido, o trabalho escravo dá espaço ao trabalho assalariado no Brasil. De certa forma, a industrialização teve grande importância, porque privilegiou a burguesia, a qual foi favorecida, economicamente, na área industrial.

Além disso, por insatisfação da maior parte da sociedade, a monarquia, incapaz de conduzir as transformações em processo, foi banida, dando lugar à República, em 1889. Nesse ponto, Bosi (2006, p. 163) declara que “[...] os anos de 60 tinham sido fecundos como preparação de uma ruptura mental com o regime escravocrata e as instituições políticas que o sustentavam". Relativo a essa ideia, o sumo dessas críticas e revoluções políticas já se encontravam nas páginas de um espírito realista e democrático (BOSI, 2006).

É nesse contexto que a Literatura foi marcada por transformações estéticas, tendo dois grandes movimentos literários atenuantes: o Realismo e o Naturalismo (COUTINHO, 2004). Ambos tiveram sua primeira aparição na França em meados do século XIX, tendo como precursores Gustave Flaubert e Émile Zola, respectivamente. Esses novos movimentos literários tinham como finalidade produzir uma nova arte que abandonasse o subjetivismo romântico (MOISÉS, 1985), rompendo as ideias tradicionais, que já não eram mais suficientes, adotando um teor crítico-social mais realista.

Contrapondo-se a subjetividade romântica, Bosi (2006, p. 167) afirma que:

O romântico não teme as demasias do sentimento nem os riscos da ênfase patriótica; nem falseia de propósito a realidade, como anacronicamente se poderia hoje inferir: é a sua forma mental que está saturada de projeções e identificações violentas, resultando-lhe natural a mitização dos temas que escolhe. Ora, é esse complexo ideo-afetivo que vai cedendo a um processo de crítica na literatura dita 'realista'. Há um esforço, por parte do escritor antirromântico, de acercar-se impessoalmente dos objetos, das pessoas. E uma sede de objetividade que responde aos métodos científicos cada vez mais exatos nas últimas décadas do século. 
Seguindo esse pressuposto, a idealização romântica nacionalista e sentimentalista é deixada de lado pelos autores realistas que não concordavam com esse subjetivismo exacerbado e buscavam, para a prosa ficcional, temáticas totalmente voltadas para a sociedade, sendo mais diretamente ligados à realidade da época.

Ainda nessa linha de pensamento, Bosi (2006, p. 169) declara que:

[...] As vicissitudes que pontuaram a ascensão da burguesia durante o século XIX foram rasgando os véus idealizantes que ainda envolviam a ficção romântica. Desnudam-se as mazelas da vida pública e os contrastes da vida íntima; e buscam-se para ambas causas naturais ( raça, clima, temperamento) ou as culturas (meio,educação) que lhes reduzem de muito a área de liberdade. O escritor realista tomará a sério as suas personagens e se sentirá no dever de descobrir-lhes a verdade, no sentido positivista de dissecar os móveis de seu comportamento.

Observa-se que o autor realista, por meio da observação fiel da realidade, procura revelar a verdadeira face da população, tendo o propósito de desmascarar a hipocrisia da sociedade em questão. Desse modo, os realistas procuravam retratar temas desafiadores e, por vezes, sórdidos, visto que chegavam a constranger a sociedade da época. Ao contrário do Romantismo, a temática amorosa deixa de ser subjetiva e se torna alvo de críticas, pois a infidelidade matrimonial passa a ter um espaço primário nessa narrativa.

O Naturalismo, assim como o Realismo, também procura criticar a sociedade, entretanto, o Naturalismo é uma ampliação do Realismo. Assim, Bosi (2006, p. 168, grifos no original) afirma que "o Realismo se tingirá de naturalismo, no romance e no conto, sempre que fizer personagens e enredos submeterem-se ao destino cego das 'leis naturais' que a ciência da época julgava ter codificado [...]". Seguindo esse ponto de vista, o Naturalismo e o Realismo caminham lado a lado, por mostrarem a realidade dos fatos, embora haja suas particularidades, já que o Naturalismo define-se principalmente por adotar, em seus romances, teorias científicas.

Com o propósito de uma nova arte literária, o Naturalismo tem como uma de suas finalidades averiguar o meio social, procurando explorar o que antes era ocultado pela estética romântica. Desse modo, Bosi (2006, p. 172, grifos do autor) descreve que:

A mente cientificista também é responsável pelo esvaziar-se do êxtase que a paisagem suscitava nos escritores românticos. Os que se entende pela preferência dada agora aos ambientes urbanos e, em nível mais profundo, pela não-identificação do escritor realista com aquela vida e aquela natureza 
transformadas pelo Positivismo em complexos de normas e fatos indiferentes à alma humana.

Sendo assim, essa nova estética literária propunha-se a observar e criticar a natureza humana por meio de romances de cunho científico, revelando personagens corrompidos pelo meio. A esse respeito, segundo Bosi (2006, p. 172) “[...] o naturalista julga 'interessante' o patológico, porque prova a dependência do homem em relação à fatalidade das leis naturais". Desta forma, os naturalistas buscavam, na Fisiologia, respostas sobre os problemas que eram encontrados na sociedade. O Naturalismo segue ainda a tese determinista de Taine, defendendo a ideia de que o meio interfere no caráter e comportamento do indivíduo. Nessa perspectiva, Bosi (2006, p.172) acrescenta que:

O determinismo reflete-se na perspectiva em que se movem os narradores ao trabalhar as suas personagens. A pretensa neutralidade não chega ao ponto de ocultar o fato de que o autor carrega sempre tons sombrios o destino de suas criaturas.

Desse modo, de acordo a perspectiva do autor, a teoria determinista impõe que o ser humano é incapacitado de tomar suas próprias decisões, sendo que ele não tem autonomia para escolher seu destino, revelando que a natureza é superior à sua vontade. A herança genética também é um fator de forte influência ao caráter das personagens e, nesse sentido, Coutinho (2004, p. 11) afirma que "o homem nada é senão uma máquina guiada pela ação das leis físicas e químicas, pela hereditariedade e pelo meio físico e social". Dito isto, o comportamento humano é explicado com base no meio no qual está inserido e pelos traços genéticos que determinarão sua conduta.

\section{A Condição Feminina: a ascensão do discurso sexual na sociedade do século XIX}

Durante muito tempo, a sexualidade foi um tabu no meio social, visto que era constrangedor falar sobre determinado assunto, o sexo era reprimido, o simples fato de falar dele e seu interdito configura um ar de transgressão deliberada (FOUCAULT, 2006). Porém, no século XIX, houve uma proliferação do discurso sexual que marcaria tal período. Desta forma, o sexo passou a ser associado ao pecado pela sociedade cristã, de modo que era uma atividade completamente vigiada e restringida pela Igreja que, por meio de regras, buscava controlar a conduta sexual, principalmente, da mulher. 
Nesse período, a sexualidade estava cercada por manifestações discursivas que desejavam interditar atos lascivos vinculados ao prazer carnal. Assim, a Igreja obteve forte apoio de outras instituições sociais, como pedagógicas, judiciárias e médicas (FOUCAULT, 2006). Nessa perspectiva, salienta-se que, mesmo com essa censura, não foi possível evitar a transgressão da moral imposta pela sociedade, visto que a banalização do sexo provocava ainda mais o estímulo da volúpia.

Castello Branco (2004, p. 53), acerca da sexualidade no século XIX, afirma:

O século XIX é conhecido como o período da sexualidade encarcerada, muda e hipócrita. E, no entanto, é nessa época que proliferam textos exibindo corpos nus e "perversões" de toda espécie. É lógico que essas ousadias eram permitidas porque, através do estudo e da análise dos chamados fenômenos anormais, o que se buscava era exatamente defender a normalidade e a ordem.

De acordo com tal descrição, a sexualidade no século XIX, mesmo que por muita repressão, foi alvo de curiosidade, tendo destaque, principalmente, nas obras realistas/naturalistas, nas quais era detalhadamente descrita, explorando, por essência, o desejo e seu lado patológico. Nas obras naturalistas, havia aspectos que buscavam levar à centralização da narrativa temática que circundava a transgressão sexual.

As relações sexuais fora do espaço matrimonial eram vistas como comportamentos vergonhosos e imorais, pois infringiam as regras impostas pela sociedade da época. Dessa forma, Bulhões (2003, p. 37) ressalta "que o sexo ficou resguardado no mais recôndito espaço da intimidade: o quarto da família burguesa”. Desse modo, Foucault (2006) complementa ao afirmar que o quarto dos pais era tido como o lugar correto para a prática das relações sexuais, visto que apenas em local apropriado era possível ligá-lo à reprodução. Logo, o ato sexual tinha como finalidade somente a procriação.

Além da imposição do cristianismo acerca da sexualidade, a medicina, apoiada nas teorias cientificistas predominantes na época, passou a interferir de forma repressora na questão sexual, conforme retrata Castello Branco (2004, p. 48) ao afirmar que:

[...] não é apenas através de preceitos religiosos ou determinadas práticas sociais, como o trabalho, que a repressão sexual se efetua em nossa cultura. Há formas sutis de controle da sexualidade que atravessam nossa vida diária e determina nossa maneira de conceber e de vivenciar o erotismo. Uma delas, que se instalou definitivamente em nossa cultura e, sobretudo a partir do século XIX, e que parecem ter substituído a Igreja em rigor e eficácia, é a ciência. 
Conforme exposto pela autora, a ciência, vinculada ao discurso médico, propagava a ideologia que determinava o comportamento sexual dito "correto" a ser seguido pela sociedade. De acordo com isso, o cientificismo disseminou o pensamento de que as relações íntimas ocorridas fora do casamento eram vistas como aberrações e patologias sexuais.

Assim, no século XIX, o cientificismo, auxiliado pelo discurso médico e pela Igreja, passou a fazer proibições às diversas formas de prazer. Ademais, a ciência procurava diagnosticar, no intuito de solucionar essas condutas tidas como "desviantes" (CASTELLO BRANCO, 1985). Dessa forma, a ciência assumiu o dever de examinar criteriosamente os tipos de comportamentos sexuais fora do matrimônio, atribuindo, com convicção, que todas essas práticas lascivas ilícitas eram consideradas doenças do organismo biológico e/ou perversões sexuais anormais.

\section{$O$ Cortiço: a sexualidade feminina sob a ótica da personagem Pombinha}

A princípio, antes de adentrar na análise da personagem Pombinha, é importante salientar que a obra $O$ Cortiço ([1890] 2012) dá cabimentos para várias interpretações referentes à temática do erotismo e sexualidade. Ressaltando-se que tal tema é abrangido em diversas personagens do romance, portanto essa análise limita-se a investigar o comportamento erótico-sexual da personagem citada, na intenção de abarcar sobre a construção e o desenvolvimento da sua sexualidade no decorrer da obra.

Pombinha é representada no romance como uma personagem pura, delicada, ingênua e enferma, principalmente, por ainda não “tornar-se mulher”. Filha de D. Isabel "uma pobre mulher comida de desgostos" (AZEVEDO, [1890] 2012, p. 42), que fora casada com um comerciante que faliu e, posteriormente, suicidou-se, "deixando-lhe uma filha muito doentinha e fraca, a quem Isabel sacrificou tudo para educar, dando-lhe mestre até de francês" (AZEVEDO, [1890] 2012, p. 42). A narrativa ainda relata que:

A filha era a flor do cortiço. Chamavam-lhe Pombinha. Bonita, posto que enfermiça e nervosa ao último ponto; loira, muito pálida, com uns modos de menina de boa família. A mãe não lhe permitia lavar, nem engomar, mesmo porque o médico o proibira expressamente. (AZEVEDO, [1890] 2012, p. 42).

Nesse excerto, explicita-se que a personagem tem, além da sua pureza e delicadeza, uma educação exemplar, visto que "nas famílias aristocráticas [...] as meninas aprendem equitação e as línguas estrangeiras principalmente o francês" (PERROT, 2007, p. 94). Essas são 
características peculiares para o ambiente onde vivia. Além disso, há o interdito médico para que não faças atividades domésticas que possam complicar a sua problemática, como evidenciamos no seguinte excerto:

É que Pombinha, orçando aliás pelos dezoito anos, não tinha ainda pago à natureza o cruento tributo da puberdade, apesar do zelo da velha e dos sacrifícios que esta fazia para cumprir à risca as prescrições do médico e não faltar à filha o menor desvelo. No entanto, coitadas! (AZEVEDO, [1890] 2012, p. 42).

A pobre donzela, mesmo com a idade um pouco elevada para aflorar-se mulher, ainda não fora visitada pelas regras. A moçoila já prometida ao seu noivo, “o João da Costa, moço do comércio, estimado do patrão e dos colegas, com muito futuro e que a adorava e conhecia desde pequenita" (AZEVEDO, [1890] 2012, p. 42), esperava somente que sua puberdade chegasse para que o casório fosse concretizado. No entanto, assim como era comum no século XIX, D. Isabel não queria que o casamento se fizesse já, ela entendia que não era decente dar homem a uma moça, sua filha, que ainda não tivesse se tornado mulher, pois "o casamento, 'arranjado' pelas famílias e atendendo a seus interesses, pretende ser aliança antes de ser amor" (PERROT, 2007, p. 46), a mãe tinha pretensões, principalmente, econômicas com a realização do casório.

A moça era muito querida na estalagem tanto pela sua boa educação e bons modos como pela sua prestatividade para com os outros moradores:

Pombinha era muito querida por toda aquela gente. Era quem lhe escrevia as cartas; quem em geral fazia o rol para as lavadeiras; quem tirava as contas; quem lia o jornal para os que quisessem ouvir. Prezavam-na com muito respeito e davam-lhe presentes, o que lhe permitia certo luxo relativo. Andava sempre de botinhas ou sapatinhos com meias de cor, seu vestido de chita engomado; tinha as suas joiazinhas para sair à rua, e, aos domingos, quem a encontrasse à missa na Igreja de São João Batista, não seria capaz de desconfiar que ela morava em um cortiço. (AZEVEDO, [1890] 2012, p. 43).

Como retratado nesse trecho, Pombinha era bem-apessoada e muito querida, prestava serviços aos moradores do cortiço que não tinham o domínio das letras e dos números. Decorrente disso, ganhava presentes que lhes davam uma aparência mais requintada e luxuosa, o que lhe dava um ar de superioridade que os próprios moradores aludiam. Sempre aos domingos ela ocupava-se com as correspondências dos moradores "[...] numa pequena mesa, [...] a menina escrevia, enquanto o dono ou dona da carta ditava em voz alta o que queria mandar dizer à família ou a algum mau devedor de roupa lavada" (AZEVEDO, [1890] 2012, p. 66), 
carta após carta sendo sempre a sós, um de cada vez, pois nenhum queria dar o seu recado à presença de outra pessoa além de Pombinha.

Um fator que muda profundamente a moça é o surgimento da personagem Léonie no romance. Essa era comadre da Augusta e Alexandre e quem cuidava de Juju, filha do casal e a “[...] trazia sempre muito bem calçada e vestida a afilhada" (AZEVEDO, [1890] 2012, p. 102) para visitar seus pais. Léonie tinha a pequenina como a coisa boa da sua vida de cansaços depravados, era o que lhe radiava alegria, resgatava-a das abjeções do ofício.

No decorrer da visita de Léonie à estalagem, ela questiona por Pombinha que, no entanto, encontrava-se ausente do cortiço. A prostituta demonstra bastante interesse na jovem moça, como se vê no diálogo abaixo:

- E a Pombinha?... - perguntou a visita. - Não me apareceu ainda!...

- Ah! - esclareceu Augusta. - Não está aí, foi à sociedade de dança com a mãe.

E, como a outra mostrasse na cara não ter compreendido, explicou que a filha de D. Isabel ia todas as terças, quintas e sábados, mediante dois mil-réis por cada noite, servir de dama numa sociedade em que os caixeiros do comércio aprendiam a dançar.

- Foi lá que ela conheceu o Costa... - acrescentou.

- Que Costa?

- O noivo! Então a Pombinha já não foi pedida?

- Ah, sei...

E a cocote perguntou depois, abafando a voz:

- E aquilo?... Já veio afinal?...

- Qual! Não é por falta de boa vontade da parte delas, coitada! (AZEVEDO, [1890] 2012, p. 104).

Nesse excerto, observa-se um pequeno indício de interesse da prostituta sobre a moçoila, visto que gostavam-se muito uma da outra. Então, antes que Léonie deixasse a estalagem, Pombinha e sua mãe D. Isabel chegam da sociedade de dança, "a cocote recebeu-a com exclamações de agrado e beijou-a nos dentes e nos olhos repetidas vezes" (AZEVEDO, [1890] 2012, p. 106). Aparenta-se muito apreço e carinho entre as duas, mas fica explicitado que a cocote tem um encanto a mais pela pureza da jovem.

Por algum tempo tiveram uma conversa amiga, em que ambas demonstravam bastante afeição, desligando-as completamente dos que ali também estavam. Então, Léonie presenteia Pombinha com uma medalha de prata. Nota-se que o interesse pela moça é mais que amigável. Dessa maneira, a prostituta convida Pombinha para uma visita à sua casa. Tal convite, que fora aceito por D. Isabel, mas que ficara marcado para o domingo seguinte, revela um interesse maior que o amigável e cordial. A prostituta tinha uma sede voraz e apaixonante pela donzela, 
mas esta última não imaginaria isso, porquanto tinha, em sua essência, muita pureza e ingenuidade. Daí em diante iniciará um processo de transformação com a personagem analisada, como será descrito mais adiante.

Por conseguinte, o dia da visita de D. Isabel e Pombinha à casa de Léonie chegara. A cocote as recebe amistosamente como boa anfitriã, radiante por "acompanhar a jovem junto de si, naqueles divans fofos e traidores" (AZEVEDO, [1890] 2012, p. 127, grifos no original). A prostituta ordenou a criada que não deixasse ninguém entrar à casa “[...] e assentou-se ao lado da menina, bem juntinho uma da outra, tomando-lhe as mãos, [...] e pedindo-lhe beijos, que saboreava gemendo, de olhos fechados" (AZEVEDO, [1890] 2012, p. 127). Léonie acariciavaa demasiadamente, deixando explicito o seu desejo pela moçoila, que por ingenuidade e apreço pela cocote, não identificava nenhuma outra intenção a não ser a cordialidade e empatia que uma tinha na outra.

Durante a refeição, às duas da tarde, servida pelas suas próprias mãos, Léonie deixa ainda mais claro suas intenções com a menina, “[...] sem se descuidar um instante da rapariga, tinha para ela extremas solicitudes de namorado; levava-lhe a comida à boca, bebia do seu copo, apertava-lhe os dedos por debaixo da mesa" (AZEVEDO, [1890] 2012, p. 12). Após o desjejum, D. Isabel que não era habituada a saborear vinho foi descansar em um quarto, acomodada por Léonie, deixando Pombinha a sós com a prostituta, foi então que a cocote demonstrara à menina que por ela possuía sentimentos passionais e libidinosos:

- Vem cá minha flor!... - disse-lhe, puxando-a contra si e deixando-se cair sobre um divan. Sabes? Eu te quero cada vez mais!... Estou louca por ti!

E devorava-a de beijos violentos, repetidos, quentes, que sufocavam a menina, enchendo-a de espanto e de um instintivo temor, cuja origem a pobrezinha, na sua simplicidade, não podia saber qual era. A cocote percebeu seu enleio e ergueu-se, sem largar-lhe a mão(AZEVEDO, [1890] 2012, p. 128, grifos no original).

A pobre menina ficara extremamente constrangida, sem jeito, amedrontada. Léonie demonstrara claramente que Pombinha era, de acordo com Bataille (2013), o interesse triunfante do ser pessoal e do limite, deixando diante do objeto desejado, objeto significativo da negação dos limites, do objeto erótico que lhe arfava. Foram para alcova, onde Pombinha, toda perplexa, tentou reatar o fio da conversa que elas sustentavam, ainda à mesa, com D. Isabel. Porém, Léonie fingia dar ouvidos à conversa e nada mais fazia do que: 
[...] afagar-lhe a cintura, as coxas e o colo. Depois, como que distraidamente, começou a desabotoar-lhe o corpinho do vestido.

- Não! Para quê?... Não quero despir-me...

- Mas faz tanto calor... Põe-te a gosto...

- Estou bem assim. Não quero!

- Que tolice a tua! Não vês que sou mulher, tolinha?... De que tens medo?... Olha! Vou dar o exemplo!

E, num relance, desfez-se da roupa, e prosseguiu na campanha.

A menina, vendo-se descomposta, cruzou os braços sobre o seio, vermelha de pudor.

- Deixa! - segredou-lhe a outra, com os olhos envesgados, a pupila trêmula.

$\mathrm{E}$, apesar dos protestos, das súplicas e até das lágrimas da infeliz, arrancoulhe a última vestimenta, e precipitou-se contra ela, a beijar-lhe todo corpo, a empolgar-lhe com os lábios o róseo bico do peito (AZEVEDO, [1890] 2012, p. 128-129).

Nesse ínterim, mesmo com a relutância da menina, a prostituta sedenta de libido consegue a consumação dos fatos explicitada no excerto seguinte:

Pombinha arfava, relutando; mas o atrito daquelas duas grossas pomas irrequietas sobre o seu mesquinho peito de donzela impúbere e o roçar vertiginoso daqueles cabelos ásperos e crespos nas estações mais sensitivas da sua feminilidade, acabaram por foguear-lhe a pólvora do sangue, desertando-lhe a razão ao rebate dos sentidos (AZEVEDO, [1890] 2012, p. 129).

É possível perceber no trecho acima, que mesmo a moça tendo lutado contra, a insistência e o atrito dos corpos e da feminilidade, fez com que ela cedesse ao desejo, neste sentido segundo Alberoni (1993, p. 38) “[...] o estímulo sexual deve ser, ao mesmo tempo, recusa, obstáculo". E a prostituta tendo o seu corpo, sedento de prazer, faz menção a um ato erótico vinculado ao imaginário humano (PAZ, 2001), pois exibir sua nudez e influenciar áreas sensíveis reproduz uma imagem sexual na mentalidade da personagem. A avidez do prazer acaba transformando-as como retratado no fragmento seguinte:

Agora, espolinhava-se toda, cerrando os dentes, fremindo-lhe a carne em crispações de espasmo; ao passo que a outra, por cima, doida de luxúria, irracional, feroz, revoluteava, em corcovos de égua, bufando e relinchando. E metia-lhe a língua tesa pela boca e pelas orelhas, e esmagava-lhe os olhos debaixo dos seus beijos lubrificados de espuma, e mordia-lhe o lóbulo dos ombros, e agarrava-lhe convulsivamente o cabelo, como se quisesse arrancálo aos punhados. Até que, com um assomo mais forte, devorou-a num abraço de todo o corpo [...] (AZEVEDO, [1890] 2012, p. 129). 
Nesse sentido, percebe-se que o ato libidinoso entre Léonie e a Pombinha é descrito minuciosamente, sendo relatado conforme a teoria darwinista (zoomorfismo), onde ambas assumem comportamentos semelhantes a animais, nesse aspecto, Bataille (2013, p. 118) afirma que "a animalidade é mesmo tão bem mantida no erotismo, que o termo animalidade, ou bestialidade, não cessa de lhe estar ligado". Conclui-se que ambas sentem-se realizadas e deixam aflorar, principalmente na donzela, sentimentos de libido que a jovem nunca havia sentido.

A menina, mal orientada, impudica, voltara a si envergonhada cingindo-se aos travesseiros, tentando abafar o seu pranto. Enquanto vestia-se exclamava "Não volto mais aqui! Nunca mais!” (AZEVEDO, [1890] 2012, p. 130). Léonie, desesperada, tentava de todas as formas acalmar Pombinha, e por insistência de reconciliação lhe pede mais um beijo, sendo cedido pela moça. $\mathrm{O}$ jantar corre friamente, pois Pombinha se mostrava bastante incomodada e D. Isabel sentia-se ainda aziada por ter dormido por tanto tempo. A cocote tomou a mão de Pombinha e meteu-lhe no dedo um anel, que foi recusado, a princípio, mas por insistência da mãe a moçoila o aceita. Após esse momento as visitas retiram-se, seguindo diretamente para a estalagem. Pombinha aparenta estar preocupada e triste durante toda a viagem.

Na manhã seguinte, Pombinha não muito disposta às atividades rotineiras que cumpria, torceu o nariz para o almoço preparado por D. Isabel com muito esmero, persistiam-lhe dores uterinas, não muito fortes, mas constantes. Por volta do meio-dia sentia-se tamanho desassossego entre aquelas pequenas paredes do quarto 15 que resolveu sair e dar uma volta por detrás do cortiço. Uma irresistível necessidade de estar só, "uma aflição de conversar consigo mesma" (AZEVEDO, [1890] 2012, p. 132). Pôs-se à sombra dos bambus e das mangueiras. "Pungia-lhe na brancura da alma virgem um arrependimento incisivo e negro das torpezas da antevéspera; mas, lubrificada por essa recordação, toda a sua carne ria e rejubilavase" (AZEVEDO, [1890] 2012, p. 132), Pombinha pressentia as delícias que lhe eram reservadas para após o casório com o amado, dentro de si, agora, haviam desejos que antes eram mudos e adormecidos. Mudanças e mistérios desvendavam-se no seu corpo, "enchendo-a de surpresa e mergulhando-a em fundas concentrações de êxtase" (AZEVEDO, [1890] 2012, p. 132). Nesse júbilo, a moça adormece e logo começa a sonhar que:

[...] em derredor ia tudo se fazendo de um cor-de-rosa, a princípio muito leve e transparente, depois mais carregado, e mais, e mais, até formar-se em torno dela uma floresta vermelha, cor de sangue, onde largos tinhorões rubros se agitavam lentamente. E viu-se nua, toda nua, exposta ao céu, sob a tépida luz 
de um sol embriagador, que lhe batia de chapa sobre os seios (AZEVEDO, [1890] 2012, p. 133).

O sonho continua ficando cada vez mais intenso, causando-lhe suspiros, Pombinha espreguiçou-se toda num enleio de volúpia ascética. "Lá do alto o sol a fitava obstinadamente, enamorado das suas mimosas formas de menina" (AZEVEDO, [1890] 2012, p. 133). A moça sorria, requebrando os olhos, mas de repente:

[...] nem que se de improviso lhe inflamassem os desejos, precipitou-se lá de cima agitando as asas, e veio, enorme borboleta de fogo, adejar luxuriosamente entorno da imensa rosa, em cujo regaço a virgem permanecia com os peitos franqueados.

E a donzela, sempre que a borboleta se aproximava da rosa, sentia-se penetrar de um calor estranho, que lhe ascendia, gota a gota, todo o seu sangue de moça (AZEVEDO, [1890] 2012, p. 133).

Nesse aspecto, compreende-se que essa metáfora representa o ingresso da personagem para a vida como mulher. Metamorfoseara-se como flor que desabrocha, "a rosa que tinha ao colo", representava a sua vagina, que sempre que "a borboleta avizinhava, [...] a flor arregaçavase toda, dilatando as pétalas, abrindo o seu pistilo vermelho e ávido daquele contato com a luz" (AZEVEDO, [1890] 2012, p. 133-134). Nota-se claramente que a borboleta representa o estopim para que ocorresse o derramamento de sangue, ocasionado pelo dilatamento natural do útero no determinado período menstrual.

Outro episódio que revelaria uma nova personalidade em Pombinha foi uma conversa com o ferreiro Bruno, que lhe pediu que escrevesse uma carta para a esposa, Leocádia, a qual havia colocado porta a fora de casa por tê-lo traído.

- Vamos lá, Bruno! Que queres tu mandar dizer à Leocádia?

- Diga-lhe, antes de mais nada, que aquilo que quebrei dela, que dou outro! Que ela fez mal em quebrar também o que era meu, mas que fecho os olhos! Águas passadas não movem moinho! Que sei que ela agora está desempregada e aos paus; que está a dever para mais de mês na estalagem; mas que não precisa dar cabeçadas: que me mande cá o senhorio, que me entendo com ele. Que acho bom que ela deixe a casa da crioula onde come, porque a mulher já se queixou e já disse, a quem quis ouvir, que aquilo lá não era ponto de vadios e mulheres de má vida! Que ela, se tivesse um pouco de tino nem precisava estar às migalhas dos outros, que eu na forja fazia para a trazer de barriga cheia e mais aos filhos que Deus mandasse... - principiava a tomar calor. - Que a culpada de tudo isto é só ela e mais ninguém! tivesse um bocado de juízo e não precisava envergonhar a cara por aí...

[...] depois de coçar mais vivamente a cabeça, gaguejou com a voz estrangulada de soluços: 
- Diga-lhe que... se ela quiser tornar para minha companhia... que pode vir... Eu esqueço tudo! (AZEVEDO, [1890] 2012, p. 138).

Pombinha fica completamente impressionada pela transformação no semblante de Bruno, vendo o pobre ferreiro inundar-se em lágrimas. "E, coisa estranha, ela, que escrevera tantas cartas naquelas mesmas condições; [...] sobressaltava-se agora com os desalentados soluços do ferreiro" (AZEVEDO, [1890] 2012, p. 138). Neste sentido, percebe-se que, após sentir o primeiro grito de mulher, Pombinha teve novo "olhar para esses devaneios violentos e doloroso, a que os poetas davam o bonito nome de amor" (AZEVEDO, [1890] 2012, p. 138).

A sua intelectualidade, assim com seu corpo, desabrochara e em pleno desenvolvimento, uma lucidez a surpreendia, como se naquele instante o mundo inteiro se despia ao seu olhar. Observando as lagrimas do ferreiro, ela compreendeu a fraqueza dos homens, a fragilidade, que apesar de serem "animais fortes", se deixam encabrestar e serem conduzidos pela mão feminina. No trecho que segue, observa-se que Pombinha havia se transformado de acordo com o meio ao qual sua maturidade desabrochara, assim como explicita a tese determinista:

Aquela pobre flor do cortiço, escapando à estupidez do meio em que desabotoou, tinha de ser fatalmente vítima da própria inteligência. À míngua de educação, seu espírito trabalhou à revelia, e atraiçoou-a, obrigando-a a tirar da substância caprichosa da sua fantasia de moça ignorante e viva a explicação de tudo que lhe não ensinaram a ver e sentir.

[...] E surgiu-lhe então uma ideia bem clara da sua própria força e do seu próprio valor.

Sorriu. E no seu sorriso já havia garras (AZEVEDO, [1890] 2012, p. 139).

Pombinha, agora, já não tinha mais o mesmo olhar que tinha para os homens, os via com desprezo e superioridade, tinha em si que a fêmea é que tinha o domínio e não os machos, contrapondo toda a cultura da sociedade da época em que tinha o sexo feminino como carente, defeituoso e uma fraqueza própria de sua natureza (PERROT, 2007).

Desse modo, a moça pensou em todos os homens da estalagem em como eram submissos em relação às mulheres: o Firmo e o Jerônimo estrebucharem-se, como dois cães que disputam o amor da Rita Baiana; e viu o Miranda, subalterno ao lado da esposa infiel; viu o Domingos perdendo seu emprego e suas economias só para ter momentos de luxúria com a Florinda. A partir disso, a moça pressentiu que nunca daria de si ao marido que "nunca o respeitaria sinceramente como a um ser superior por quem damos a vida, [...] e, por conseguinte nunca lhe teria amor" (AZEVEDO, 2012, p. 140). Achava-o fraco, passivo e resignado como 
os outros, que não tinha ambição, "era mais um animal que viera ao mundo para propagar a espécie” (AZEVEDO, [1890] 2012, p. 140).

Sendo assim, após o fim dos seus primeiros dois anos de casamento, ela já não suportava mais o marido, "[...] para conservar-se mulher honesta, tentou perdoar-lhe a falta de espírito, os gostos rasos, [...] a palermice de homem sem ideal" (AZEVEDO, [1890] 2012, p. 214). Desta maneira, Pombinha cai nos braços de um "boêmio de talentos", Costa não soube de princípio, mas estranhou a mulher, passou a desconfiar, a espreita-la, até que um dia "o desgraçado teve a dura certeza de que era traído pela esposa” (AZEVEDO, [1890] 2012, p. 215). O marido devolve a esposa para mãe, D. Isabel, que afunda-se em lágrimas, aconselhando a filha que mude de conduta e volte ao marido. Pombinha deixa a casa da mãe e só é encontrada semanas depois em um hotel com a Léonie. "A serpente vencia afinal: Pombinha foi pelo seu próprio pé, atraída, meter-se na boca" (AZEVEDO, [1890] 2012, p. 215), que de acordo com o determinismo segundo o qual o homem é condicionado pelos fenômenos que vivenciou, passando a ser deles consequência Assim, fatores como o meio social e a herança genética explicam as decisões e comportamentos.

Dessa forma, a personagem analisada passou por uma transformação no decorrer dos acontecimentos, sendo está completamente influenciada após as relações que tivera e a partir da sua percepção comportamental dos homens. Assim, passando a ter uma visão mais feminista de si mesmo, quebrando paradigmas até então fundamentalmente seguidos com base nos ensinamentos religiosos.

Por fim, Pombinha, junto com Léonie, vivia da prostituição. De acordo com Bataille (2013, p. 87), Pombinha agora "se consagrava à transgressão [...], isto é, o aspecto do interdito da atividade sexual, não deixava de aparecer", sendo assim, a nova cocote dedicaria sua vida inteira a violação desse interdito, ou seja, passava agora a ser, assim como Léonie, "mulher da vida". Mesmo em tal movimento de transgressão, ela passava ter uma independência que não era bem vista à sociedade do século XIX, mas que explanava que a mulher não necessitava da imposição social que lhes obrigava à submissão ao homem.

\section{CONSIDERAÇOES FINAIS}

Este trabalho procurou explanar, no romance naturalista $O$ Cortiço ([1890] 2012), a temática erótico-sexual, tendo como abordagem central a análise da sexualidade e o erotismo presente na personagem Pombinha, bem como as consequências que os meios causaram ao seu 
desenvolvimento como mulher. Dentre os aspectos analisados, no que concerne à sexualidade, onde a transgressão foi um dos fatores principais, devido o comportamento da personagem ter mudado e se afastado dos padrões estabelecidos pela sociedade da época, pois ela passa de moça pura e ingênua para uma mulher dona de si mesma e independente. Além disso, foi capaz de perceber que tinha um poder sobre os homens, visto que, os via como fracos e passivos.

Embasado por alguns teóricos como Bataille (2013), Castelo Branco (1985) e (2004) e Foucault (2006), foi possível averiguar que os conceitos de sexualidade e erotismo presentes na personagem estavam relacionados à descontinuidade, pois Pombinha ao descobrir-se mulher, percebe que não tem necessidade de uma vida amorosa, encharcada de sentimentalismo, além disso, ver-se distante de uma vida matrimonial, pois para ela, seria incapaz de amar o marido e tornar-se submissa às leis do casamento.

Dessa forma, ressalta-se que, apesar da personagem Pombinha não ser protagonista do romance, é impossível não atentar à sua presença, devido sua presença marcante e gradativa que enlaça vários outros personagens, desde a sua primeira menção como jovem moça pura e que ainda não era mulher. Essa personagem no decorrer da obra também se caracteriza pela sua evolução, principalmente após sua relação libidinosa com a cocote Léonie e sua passagem de fase natural, tornando-se posteriormente desvinculada de padrões sociais da época, obtendo a sua independência, esse fato é importante porque ilustra que a mulher pode ter uma vida sem os anseios do casamento, sem a necessidade de submissão ao homem.

Por fim, conclui-se que desenvolvimento da sexualidade em Pombinha foi o principal responsável em provocar transgressões aos interditos impostos pela sociedade no XIX, por essência, abarcados pela Igreja e pelas bases teóricas cientificas de tal contexto que proibiam relações sexuais fora do casamento, nomeando-as como patologias. Nesse aspecto, pode-se afirmar que o erotismo feminino está relacionado aos desejos íntimos, que podem se manifestar de maneira implícita e explícita através de fantasias ou de práticas sexuais.

\section{REFERÊNCIAS}

ALBERONI, Francesco. O erotismo. Tradução de Elia Edel. Rio de Janeiro: Rocco, 1993. Tradução de: L' erotismo.

AZEVEDO, Aluísio. O Cortiço. São Paulo: 8a ed. Martin Claret. [1890] 2012.

BATAILLE, Georges. O erotismo; tradução Fernando Scheibe. Belo Horizonte: Autêntica Editora, 2013.

BOSI, Alfredo. História concisa da literatura brasileira. São Paulo: 48 a ed. Cultrix 2012. 
BULHÕES, Marcelo. Leituras do Desejo: O Erotismo no Romance Naturalista Brasileiro. São Paulo: Editora da Universidade de São Paulo, 2003.

CASTELLO BRANCO, Lúcia. Eros Travestido: um estudo do erotismo no realismo burguês brasileiro. Belo Horizonte: UFMG, 1985.

CASTELLO BRANCO, Lúcia. O que é erotismo. São Paulo: Brasiliense, 2004.

CANDIDO, Antônio. Literatura e sociedade: estudos de teoria e história literária. São Paulo: $9^{\mathrm{a}}$ ed. Ouro sobre azul, 2000.

COUTINHO, Afrânio. A Literatura no Brasil. São Paulo: Global, 2004.

FOUCAULT, Michel. História da sexualidade I: A vontade de saber. Tradução de Maria Thereza da Costa Albuquerque e J.A. Guilhon Albuquerque. Rio de Janeiro, Edições Graal, 2006. Do original em frânces: Histoire de laSexualité: I: La Volonté de savoir.

FOUCAULT, Michel. História da sexualidade 2: O uso dos prazeres. Tradução de Maria Thereza da Costa Albuquerque e J. A. Guilhon Albuquerque. 13 ${ }^{\mathrm{a}}$ ed. Rio de Janeiro: Edições Graal, 2012. Tradução de: Histoire de lasexualité: l' usage de plaisir.

MOISÉS, Massaud. História da literatura brasileira: realismo. São Paulo: Cultrix: EDUSP, 1985.

PAZ, Octávio. A dupla chama: amor e erotismo. São Paulo: Siciliano, 2001.

PERROT, Michelle. Minha história das mulheres. Tradução de Angela M. S. Corrêa. São

Paulo: Contexto, 2007. 